\title{
Editorial
}

Claudia Regina Furquim de Andrade

Professora Titular

Departamento de Fisioterapia, Fonoaudiologia e Terapia Ocupacional

Faculdade de Medicina

Universidade de São Paulo

\section{Dear Readers:}

The first part of this editorial is dedicated to our new data base indexation, Scopus. One more step in a long way to consolidate a journal in a scientific community. Scopus is the largest abstract and citation database. It covers:

. 15,000 peer-reviewed journals from more than 4,000 international publishers, including coverage of: over 1200 Open Access Journals; 500 Conference Proceedings; 200 book series.

.33 million records, of which: 16 million records include references going back to 1996 (75\% include references); 17 million pre-1996 records go back as far as 1841

Scopus also covers 386 million quality web sources, including 22 million patents. Web sources are searched via Scirus, and include author homepages, university sites and resources such as the preprint servers CogPrints and ArXiv.org, and OAI compliant resources.

The articles in this number are:

Calais et al. (2008) present a research about speech perception of elderly, in silence and in the presence of background noise. For this purpose, 55 subjects of both genders, 60 years old or above, distributed in two groups were assessed: Control Group (CG), constituted by elders with no hearing loss and Study Group (SG), constituted by elders
Prezados Leitores:

A primeira parte deste Editorial é dedicada a nossa nova indexação, a Scopus. Mais uma etapa no nosso caminho para solidificar a Revista na comunidade científica. A Scopus é a maior base de dados de resumos e citações. Ela abrange:

. 15.000 Revistas arbitradas, de mais de 4.000 editoras internacionais, incluindo mais de 1.200 revistas de acesso livre; 500 anais completos de conferências; 200 séries de livros.

. 33 milhões de registros, dos quais 16 milhões incluem referências até o ano de 1996 (75\% incluem referências); 17 milhões incluem referências anteriores a 1996 retrocedendo até o ano de 1841.

A Scopus também abrange 386 milhões de recursos de qualidade da web, incluindo 22 milhões de patentes. Os recursos da web podem ser pesquisados via Scirus, e incluem homepages de autores, sites de universidades e recursos como servidores de pré publicações como CogPrints, ArXiv.org, e OAI.

Os artigos deste número são:

Calais et al. (2008) apresentaram uma pesquisa sobre a percepção de fala no silêncio e na presença de ruído em idosos. Para isto, foram avaliados 55 sujeitos de ambos os sexos, com idade a partir de 60 anos distribuídos em grupos: Grupo Controle, constituído de idosos sem perda auditiva e Grupo Estudo, constituído de idosos com perda auditiva 
with symmetrical sensorineural hearing loss. The results indicate that the presence of the noise during the production of speech sounds is disadvantageous for elders, independently of the presence of hearing loss, but having a higher impact for those with hearing loss problems.

A study about phonological therapy was presented by Keske-Soares et al. (2008). The study had as a purpose to evaluate the effectiveness of three different therapy models regarding changes in the phonological system of subjects with different phonological disorder (PD) severity levels. The research sample was constituted by 66 subjects of both genders, with ages between 4:4 and 8:2 years, who were assessed before and after a period of 15 to 25 sessions of phonological therapy. The results indicate that the three therapy approaches were effective in the treatment of children with PD, and were effective in treating different severity levels. Besides that, most of the changes occurred in the phonological system of the groups with more severe PD.

The purpose of the research presented by Pereira et al. (2008) was to identify in healthy young individuals which oropharyngeal regions are more sensitive and which stimulus is more efficient in triggering the swallowing reflex. The swallowing reflex was analyzed based on the following stimuli: spatula, cold 00 larynx mirror, gauze embedded in cold water wrapped onto spatula and frozen moist gauze wrapped onto spatula, touching the palatoglossus arch in both its inferior and superior portions, the palatine tonsils, the base of the tongue and the uvula in 65 healthy young individuals. The research concludes that when the swallowing reflex was present, the uvula, the palatoglossi arches and the palatine tonsils were the most sensitive regions to trigger this reflex and the most efficent stimuli were the cold 00 larynx mirror and the frozen moist gauze wrapped onto spatula.

Tamanaha et al. (2008) evaluated the development process of autistic children, in a direct and indirect intervention context based on the responses of 11 mothers to the Autism Behavior Checklist. These children were randomly divided into two groups: six were receiving both direct and indirect intervention (TG), and five were receiving indirect intervention exclusively (OG). The results indicate that the mothers of both groups observed behavioral changes. The authors conclude that the better scores observed for the TG are probably related to the effectiveness of direct intervention, and not to the lack of attention of parents in the neurossensorial simétrica. Os resultados indicaram que a presença do ruído juntamente com os sons de fala é prejudicial para os idosos, independente da presença da perda auditiva, sendo o impacto maior para aqueles que a possuem.

Um estudo sobre terapia fonológica foi apresentado por Keske-Soares et al. (2008), tendo como objetivo avaliar a eficácia do tratamento em três diferentes modelos de terapia quanto às mudanças no sistema fonológico de sujeitos com diferentes gravidades do Desvio Fonológico (DF). A amostra do estudo constituiu-se de 66 sujeitos de ambos os sexos, com idades entre 4:4 e 8:2 anos, sendo avaliados antes e após um período de quinze a vinte e cinco sessões de terapia fonológica. Os resultados apontaram que os três modelos de terapia aplicados foram eficazes no tratamento de crianças com DF, para as diferentes gravidades do desvio. Além disso, as maiores mudanças no sistema fonológico ocorreram para os grupos com DF de grau mais acentuado.

O objetivo da pesquisa realizada por Pereira et al. (2008) foi identificar, em indivíduos jovens e sadios, quais regiões da orofaringe são mais sensíveis para desencadear o reflexo da deglutição e qual estímuloé mais eficiente. Desta forma, o reflexo da deglutição foi investigado a partir dos estímulos: espátula, espelho laríngeo gelado, espátula envolta em gaze com água gelada e espátula envolta em gaze umedecida congelada, tocando-se o arco palatoglosso em suas porções inferior e superior, as tonsilas palatinas, a base de língua e a úvula em 65 indivíduos jovens e sadios. A pesquisa conclui que quando o reflexo da deglutição está presente, a úvula, os arcos palatoglossos e as tonsilas palatinas são as regiões mais sensíveis para desencadeá-lo e o estímulo mais eficiente, dentre os selecionados, foi o espelho laríngeo gelado e a espátula envolta em gaze umedecida congelada.

Tamanaha et al. (2008) avaliaram o processo evolutivo de crianças autistas e com síndrome de Asperger em contexto de intervenção direta e indireta a partir das respostas de 11 mães ao Autism Behavior Checklist. Essas crianças encontravamse divididas aleatoriamente em dois grupos: seis crianças em atendimento terapêutico direto e indireto (GT) e cinco apenas em atendimento indireto (GO). Os resultados indicaram que em ambos os grupos as mães observaram mudanças de comportamentos. As autoras concluem que a tendência de escores melhores do GT deveu-se, provavelmente, a eficácia da intervenção direta e não à falta de atenção dos 
OG in recognizing behavioral changes in their children.

The study of Alvarenga et al. (2008) verified the effectiveness of a training program regarding the hearing health of children for Community Health Agents of a Family Health Program. The sudy presented two groups: Group A, constituted by 31 community health agents, from Bauru, SP, and Group B, constituted by 75 community health agents, from Sorocaba, SP. The results indicate the effectiveness of the training program for community health agents, through the increase in the total score obtained in the pre and post-training questionnaires.

The research presented by Silvério et al. (2008) analyzed the vocal complaints, laryngeal symptoms, vocal habits and vocal profile of teachers of a public school before and after their participation in voice workshops. The study was divided in different steps. The results indicate that $73 \%$ of the subjects presented vocal complaints, $57 \%$ presented mild to moderate hoarseness, $78 \%$ presented breathiness and $52 \%$ presented vocal tension. After the voice workshops, a significant difference was observed in the level of vocal tension, both in the analysis of the /e/ vowel and in the analysis of spontaneous speech. Improvement was observed in vocal care and in the understanding of intervening and determinant factors for vocal alterations which are present in the teaching environment.

Masson et al. (2008) assessed the influence of a traqcheostoma humidifier (heat moisture exchanger - HME) on the control of lung secretion and esophageal and traqueoesophageal vocal quality in nine patients with total laryngectomy. The patients answered a protocol containing subjective questions related to lung secretion in three different moments: T1 (pre-use assessment of the HME), T2 (pre-use assessment of the HME six weeks after the first assessment) and T3 (assessment six weeks after the use of the HME). The results indicate that the use of the HME during the period of six weeks reduced cough and expectoration of patients with total laryngectomy. However, the use of the humidifier did not have any influence on the traqueoesophageal and esophageal vocal quality of these patients.

The research presented by Guirro et al. (2008) had as a purpose to evaluate bilaterally the electrical activity of the suprahyoid muscles ( $\mathrm{SH})$, sternocleidomastoid (SCM), and trapezius (T), the presence of pain and the voice, after applying pais do GO em reconhecer diferenças comportamentais em suas crianças.

O estudo de Alvarenga et al. (2008) verificou a efetividade de um programa de capacitação de agentes comunitários de saúde do Programa de Saúde da Família, na área de saúde auditiva infantil. O estudo apresentou dois grupos: o grupo A foi constituído por 31 agentes comunitários de saúde da Cidade de Bauru, e o grupo B foi formado por 75 agentes comunitários de saúde de Sorocaba. Os resultados apontaram a efetividade da capacitação, por meio do aumento no escore total obtido nos questionários pré e pós-capacitação.

O texto de Silvério et al. (2008) analisou as queixas, os sintomas laríngeos, hábitos relacionados com o desempenho vocal e o tipo de voz de professores de uma escola da rede pública de ensino antes e após a participação em grupos de vivência de voz. O estudo foi dividido em etapas com professores de uma escola pública. Os resultados apontaram que $73 \%$ dos sujeitos apresentaram queixas vocais, $57 \%$ apresentaram rouquidão de grau leve e moderado, $78 \%$ apresentaram soprosidade e $52 \%$ apresentaram tensão na voz. Após a vivência de voz houve diferença significativa no grau de tensão, tanto na análise da vogal /e/ como na análise da fala espontânea. O estudo aponta que houve melhora dos cuidados com a voz e a compreensão dos fatores intervenientes e determinantes das alterações vocais, presentes nas condições e organização do trabalho docente.

Masson et al. (2008) avaliaram a influência do uso do umidificador de traqueostoma (heat moisture exchanger - HME) no controle da secreção pulmonar e na qualidade vocal esofágica e traqueoesofágica de nove pacientes submetidos à laringectomia total. Os pacientes responderam a um protocolo sobre questões subjetivas relacionadas com a secreção pulmonar em três momentos, sendo T1 (avaliação pré-uso do HME), T2 (avaliação pré-uso do HME após seis semanas da primeira avaliação) e T3 (avaliação após seis semanas do uso do HME). Os resultados indicaram que o uso do HME durante seis semanas diminuiu a tosse e a expectoração em pacientes laringectomizados totais, porém não apresentou influência na qualidade vocal esofágica ou traqueoesofágica.

A pesquisa apresentada por Guirro et al. (2008) teve como objetivo avaliar a atividade elétrica dos músculos supra-hióideos ( $\mathrm{SH})$, esternocleidomastóideo (ECM) e trapézio (T) bilateralmente, a dor e a voz, após aplicação da 
transcutaneous electrical nerve stimulation (TENS), in ten women with nodules or bilateral mucus thickening, and phonation fissure. The research concludes that the TENS is effective in improving the clinical and functional signs of dysphonic women.

Rehder \& Behlau (2008) evaluated the vocal quality of 100 choir conductors of both genders, based on the production of a sustained vowel during singing and when speaking in order to observe auditory and acoustic differences. The results of the auditory-perceptive analysis of the vocal quality indicated that most conductors have adapted voices, presenting more alterations in their speaking voice and that productions differed based the voice modality, singing or speaking.

The review of the literature presented by Barreto \& Ortiz (2008) indicates that the reduction in speech intelligibility is considered one of the main characteristics of individuals with speech disorders, and is an important issue for clinical and research investigation. The authors point that in spite of its relevance, the literature does not present a consensus on how to measure speech intelligibility. The purpose of the review was to investigate evidence on the agreement between speech intelligibility measurements, obtained through different methods, used in the assessment of speech disorders, and to identify the effect of variables related to assessment procedures or to the listener. The authors conclude that there was no evidence of agreement between the speech intelligibility measurements obtained through different methods in the investigated literature. This fact limits the comparison between clinic and research results on speech intelligibility of individuals with speech disorders.

Finally, the Commentary presented by Giusti \& Befi-Lopes (2008) discusses the translation and cross-cultural adaptation of instruments to the Brazilian Portuguese language. According to the authors, it is fundamental to adopt appropriate methodological procedures when translating and adapting foreign assessment instruments so that therapists can have a better understanding about the communication disorders and their specificities in different languages.

Regards, estimulação elétrica nervosa transcutânea (TENS) em dez mulheres com nódulos ou espessamento mucoso bilateral e fenda à fonação. A partir dos resultados encontrados, a pesquisa conclui que a TENS foi eficaz na melhora do quadro clínico e funcional de mulheres disfônicas.

Rehder e Behlau (2008) avaliaram a qualidade vocal de 100 regentes de corais de ambos os sexos, nas emissões de uma vogal sustentada, nas modalidades de voz falada e cantada, com objetivo de observar diferenças auditivas e acústicas. Os resultados da análise perceptivo-auditiva da qualidade vocal indicaram que a maioria dos regentes possui vozes adaptadas, com menor desvio na voz cantada quando comparada com a falada, e que as emissões foram diferenciadas de acordo com a modalidade, voz falada ou cantada.

A revisão de literatura apresentada por Barreto e Ortiz (2008) aponta que a redução da inteligibilidade da fala é considerada uma das principais manifestações encontrada em sujeitos com distúrbios da fala e que, apesar de sua relevância, não existe consenso na literatura da área de como a inteligibilidade da fala deva ser avaliada. Diante desta afirmação, o objetivo desta revisão foi investigar a existência de possíveis evidências acerca da concordância entre medidas de inteligibilidade obtidas por diferentes métodos de mensuração, empregados na avaliação de sujeitos com distúrbios da fala, e identificar os efeitos de variáveis relacionadas com os procedimentos de avaliação ou com o ouvinte sobre essas medidas. As autoras concluem que não foram encontradas evidências, na literatura pesquisada, de concordância entre as medidas de inteligibilidade da fala obtidas por métodos distintos, o que limita a comparação entre resultados clínicos e de pesquisas sobre inteligibilidade em sujeitos com distúrbios da fala.

Para finalizar, o Comentário feito por Giusti e BefiLopes (2008) aborda o tema da tradução e adaptação transcultural de instrumentos estrangeiros para o Português Brasileiro. Para as autoras, é fundamental que nestes processos de tradução e adaptação sejam adotados procedimentos metodologicamente apropriados, que possam trazer maiores esclarecimentos acerca dos quadros de distúrbios da comunicação e de suas especificidades nas diferentes Línguas. 


\section{Referências Bibliográficas}

Alvarenga KF, Bevilacqua MC, Martinez MANS, Melo TM, Blasca WQ, Taga MFL. Proposta para capacitação de agentes comunitários de saúde em saúde auditiva. Pró-Fono Revista de Atualização Científica. 2008 jul-set;20(3):171-6.

Barreto SS, Ortiz KZ. Medidas de inteligibilidade nos distúrbios da fala: revisão crítica da literatura. Pró-Fono Revista de Atualização Científica. 2008 jul-set;20(3):201-6.

Calais LL, Russo ICP, Borges ACLC. Desempenho de idosos em um teste de fala na presença de ruído. Pró-Fono Revista de Atualização Científica. 2008 jul-set;20(3):147-52.

Giusti E; Befi-Lopes DM. Tradução e adaptação transcultural de instrumentos estrangeiros para o Português Brasileiro (PB). Pró-Fono Revista de Atualização Científica. 2008 jul-set;20(3):207-10.

Guirro RRJ, Bigaton DR, Silvério KCA, Berni KCS, Distéfano G, Santos FL, Forti F. Estimulação elétrica nervosa transcutânea em mulheres disfônicas. Pró-Fono Revista de Atualização Científica. 2008 jul-set;20(3):189-94.

Keske-Soares M, Brancalioni AR, Marini C, Pagliarin KC, Ceron MI. Eficácia da terapia para desvios fonológicos com diferentes modelos terapêuticos. Pró-Fono Revista de Atualização Científica. 2008 jul-set;20(3):153-8.

Masson ACC, Fouquet ML, Gonçalves AJ. Umidificador de traqueostoma: influência na secreção e voz de laringectomizados totais. Pró-Fono Revista de Atualização Científica. 2008 jul-set;20(3):183-8.

Pereira NAV, Motta AR, Vicente LCC. Reflexo da deglutição: análise sobre eficiência de diferentes estímulos em jovens sadios. Pró-Fono Revista de Atualização Científica. 2008 jul-set;20(3):159-64.

Rehder MIBC, Behlau M. Análise vocal perceptivo-auditiva e acústica, falada e cantada de regentes de coral. Pró-Fono Revista de Atualização Científica. 2008 jul-set;20(3):195-200.

Silverio KCA, Gonçalves CGO, Penteado RZ, Vieira TPG, Libardi A, Rossi D. Ações em saúde vocal: proposta de melhoria do perfil vocal de professores. Pró-Fono Revista de Atualização Científica. 2008 jul-set;20(3):177-82.

Tamanaha AC, Perissinoto J, Chiari BM. Evolução da criança autista em diferentes contextos de intervenção a partir das respostas das mães ao autism behavior checklist. Pró-Fono Revista de Atualização Científica. 2008 jul-set;20(3):165-70. 
